\title{
Az endoszkópos retrográd cholangiopancreatographiát követő heveny hasnyálmirigy-gyulladás megelözése
}

\author{
Patai Árpád dr. ${ }^{1}$ - Patai Árpád V. dr. ${ }^{2}$ - Solymosi Norbert dr. ${ }^{3}$ \\ Tulassay Zsolt dr. ${ }^{2}$ - Herszényi László dr. ${ }^{2}$ \\ ${ }^{1}$ Markusovszky Egyetemi Oktatókórház, Gasztroenterológiai és Belgyógyászati Osztály, Szombathely \\ ${ }^{2}$ Semmelweis Egyetem, Általános Orvostudományi Kar, II. Belgyógyászati Klinika, Budapest \\ ${ }^{3}$ Szent István Egyetem, Állatorvos-tudományi Kar, Állathigiéniai, \\ Állomány-egészségtani és Állatorvosi Etológia Tanszék, Budapest
}

\begin{abstract}
Magyarországon az évente elvégzett több mint 14000 endoszkópos retrográd cholangiopancreatographia következtében hozzávetôlegesen 1400 pancreatitis kialakulásával, ezen belül 10 beteg halálával kell számolni. A szerzők áttekintik az endoszkópos retrográd cholangiopancreatographiát követő heveny hasnyálmirigy-gyulladás megelőzésére vonatkozó szakirodalmat, ismertetik saját tapasztalataikat. Utalnak a diagnosztikus endoszkópos retrográd cholangiopancreatographia háttérbe szorulására. Hangsúlyozzák a beavatkozás javallatának gondos mérlegelését, a kockázati tényezők elemzését. Fontosnak tartják a kanülálások számának csökkentését, a korai előmetszést, a nagy kockázatú betegekben a pancreasstent beültetését, az indometacin vagy a diclofenac alkalmazását és a megfelelő intravénás folyadékbevitelt. Orv. Hetil., 2015, 156(18), 715-719.
\end{abstract}

Kulcsszavak: endoszkópos retrográd cholangiopancreatographia, szövődmények, post-ERCP-s pancreatitis, megelőzés

\section{Prevention of pancreatitis following endoscopic retrograde cholangiopancreatography}

Over 14000 endoscopic retrograde cholangiopancreatographies are performed in Hungary annually, and approximately 1400 patients are calculated to develop pancreatititis including 10 cases with lethal outcome. This article is aimed to review recent relevant literature and to present a practical guide based on the authors' own experience for the prevention of pancreatitis following endoscopic retrograde cholangiopancreatography. The authors emphasize the importance of careful consideration of indications, analysis of risk factors, avoiding unnecessary diagnostic intervention, a decrease of the attempts for cannulation, early precut, implantation of pancreatic stent in high risk patients, administration of rectal indomethacin or diclofenac and adequate intravenous fluid replacement.

Keywords: endoscopic retrograde cholangiopancreatography, complications, Post-ERCP pancreatitis, prevention

Patai, Á., Patai, Á. V., Solymosi, N., Tulassay, Z., Herszényi, L. [Prevention of pancreatitis following endoscopic retrograde cholangiopancreatography]. Orv. Hetil., 2015, 156(18), 715-719.

(Beérkezett: 2015. február 12.; elfogadva: 2015. március 13.)

\section{Rövidítések}

$\mathrm{CI}=$ megbízhatósági tartomány; $\mathrm{CT}=$ kontrasztanyagos számítógépes rétegvizsgálat; $\mathrm{ERCP}=$ endoszkópos retrográd cholangiopancreatographia; $\mathrm{MR}=$ mágnesesrezonancia-vizsgálat;
MRCP = mágnesesrezonancia-vizsgálattal végzett kontrasztanyagos cholangiopancreatographia; OD = Oddi-sphincterdyskinesis; PEP = post-ERCP-s pancreatitis 
$\mathrm{Az}$ endoszkópos retrográd cholangiopancreatographiának (ERCP) a leggyakoribb szövődménye a post-ERCP-s pancreatitis (PEP) $[1,2]$. Mivel Magyarországon évente több mint 14 ezer ERCP-t végzünk [3], így 9,7\%-os gyakorisággal [4] számolva, évente valószínúleg mintegy 1400 beteget kezelünk PEP miatt. A PEP halálozása 59 véletlen beválasztásos ellenőrzött tanulmány adatainak alapján 0,7\% (95\%-os megbízhatósági tartomány [95\% CI] 0,5-0,9\%) [4], így hazánkban a PEP hozzávetólegesen tíz beteg halálát okozhatja.

Az elmúlt évtizedben a PEP gyakoriságának és súlyosságának a csökkentésére számos sikeres módszert vezettek be, amelyek nyomán több nemzetközi és hazai ajánlás született $[5,6,7]$. Az ajánlások közötti ellentmondásokat számos összefoglalóban próbálták értelmezni, így mi magunk is [8]. Ebben a közleményben a mindennapi gyakorlat számára a saját tapasztalataink tükrében összegezzük a PEP-re vonatkozó ismereteinket.

\section{Definíció, súlyosság, gyakoriság}

A PEP klasszikus definícióját 1991-ben fogalmazták meg: 1. új vagy fokozódó pancreatitistípusú hasi fájdalom, 2. a szérumamiláznak (vagy -lipáznak) a normális felső határát háromszorosan vagy annál nagyobb mértékben meghaladó szintje a vizsgálat után 24 órával mérve, valamint 3. a kórházi kezelés legalább 2 nappal történő meghosszabbodásának a szükségessége [9]. E meghatározást a hasnyálmirigy kontrasztanyagos számítógépes rétegvizsgálata (CT) és/vagy mágnesesrezonancia-vizsgálata (MR) során észlelt kórjelekkel egészítették ki [10]. A PEP-et el kell különíteni az ERCP után 3570\%-ban jelentkező, hasi fájdalommal és a CT-n, MR-en kórjellel nem társuló hyperamylaseamiától, illetve a gyakran fájdalommal és 75\%-ban hyperamylasaemiával járó perforációtól.

A PEP enyhe, ha a kórházi tartózkodás 2-3 nappal nyúlik meg, ha nem alakul ki szervi elégtelenség, ha nincs helyi vagy szisztémás szövődmény. Mérsékelt súlyosságú a PEP, ha a szervi elégtelenség átmeneti, ha helyi szövődmény alakul ki vagy egy társbetegség súlyosbodik, ha a kórházi kezelés 4-10 nappal hosszabbodik meg. A súlyos PEP esetében 48 óránál hosszabb ideig áll fönn szervi elégtelenség, haemorrhagiás pancreatitis, pancreas- vagy peripancreaticus necrosis, pseudocysta vagy fallal határolt necrosis alakul ki, szükségessé válik percutan drenázs vagy sebészi beavatkozás, a kórházi kezelés 10 napnál hosszabb [9, 10].

A PEP gyakorisága a különböző szerzők adatai alapján széles határok között ingadozik (1,6-15,7\%) [5]. A legmegbízhatóbbnak az a közelmúltban megjelent metaanalízis tekinthető, amelyben 108, véletlen beválasztásos, ellenőrzött tanulmány kontrollcsoportjában szereplő, sem gyógyszerrel, sem pancreasstenttel nem kezelt 13296 páciens adatait összegezték: a PEP 9,7\%ban $(95 \%$ CI 8,6-10,7\%) fordult elő [4]. Lényegesen gyakoribb a PEP magas kockázatú betegekben, különösen Oddi-sphincter-diszfunkció (OD) esetén (25\%) [11], illetve normális bilirubinszintü, gyanítottan ODben szenvedő nők esetén (42\%) [12].

\section{A PEP kockázati tényezői}

A PEP kockázatát növelő tényezőket két csoportra bontják, az egyik csoportba a páciensfüggő, a másik csoportba a beavatkozással összefüggő rizikótényezőket sorolják. A szerzők megkülönböztetnek biztos és valószínű kockázati tényezóket (1. és 2. táblázat) [6, 13, 14], amelyek a metaanalízisben csak részben fedik át egymást. A nehezen kanülálható papilla fogalmát vagy a kanülálás idejével (10 percnél hosszabb) [14], vagy a kanülálási kísérletek számával (10-nél több kanülálási kísérlet) [15] szokás értelmezni, magunk az utóbbit használjuk [8]. A ritkábban végzett beavatkozások egy részét (például papillectomia, a papilla minoron [16] végzett beavatkozások) az endoszkóposok többsége fokozott kockázatú-

1. táblázat | Páciensfüggő kockázati tényezők

\begin{tabular}{l}
\hline Páciensfüggő kockázati tényezők \\
\hline Gyanított Oddi-sphincter-dyskinesis $(1,2)$ \\
Női nem $(1,4)$ \\
Korábbi pancreatitis $(1)$ \\
Fiatal életkor $(2,3)$ \\
Normális bilirubinszint $(2,3)$ \\
PEP az előzményben $(2,3)$ \\
Extrahepaticus epeutak tágulatának hiánya $(3)$ \\
Krónikus pancreatitis hiánya (3) \\
Choledocholithiasis hiánya $(4)$
\end{tabular}

(1) biztos kockázati tényező [6]; (2) biztos kockázati tényező [13]; (3) valószínü kockázati tényező [6]; (4) lehetséges kockázati tényező [13]

2. táblázat | Beavatkozásfüggő kockázati tényezők

Beavatkozásfüggő kockázati tényezők

Nehéz vagy sikertelen kanülálás $(1,2)$

Ductus pancreaticus töltés $(1,2)$

Vezetődrót bevezetése a ductus pancreaticusba $(1$ *, 2$)$

Ductus pancreaticus sphincterotomia $(2,3)$

Előmetszés $(2,3)$

Intakt epeúti sphincter ballondilatációja $(2,3)$

Acinarisatio (4)

Alacsony ERCP-s esetszám (4)

Choledocholith eltávolításának sikertelensége (3)

Intraductalis ultrahang (3)

*1-nél több alkalommal.

(1) biztos kockázati tényező [6]; (2) biztos kockázati tényező [13]; (3) valószínű kockázati tényező [6]; (4) lehetséges kockázati tényező [13] 
nak tartja, azonban az alacsony esetszámot tartalmazó, kevés közlemény alapján ezeknek a számszerúsítését nem lehetett elvégezni, ezért ezek a táblázatban nem szerepelnek.

\section{A PEP megelőzésének lehetőségei}

Mivel a PEP kialakulásának a pontos patomechanizmusa nem ismert, így több módszer komplex alkalmazása vezethet a leginkább eredményre.

\section{Az ERCP javallatának mérlegelése}

Mivel a terápiás és a diagnosztikus ERCP után kialakuló hasnyálmirigy-gyulladás gyakorisága nem tér el egymástól [13], fontos az összes diagnosztikus eszköz, elsősorban a hasi ultrahang, a sokszeletes CT, az endoszkópos ultrahang és az MR-rel végzett cholangiopancreatographia (MRCP) lehetőségeit maximálisan kihasználni, hogy a fölösleges ERCP-ket el tudjuk kerülni. Egy prospektív tanulmányunkban az ERCP-re jelöltek 21,5\%ában tartottuk indokoltnak az MRCP-t a minden esetben elvégzett klinikai és laboratóriumi vizsgálat, a hasi ultrahang, valamint a szükséges CT után, így 12,7\%-kal tudtuk csökkenteni az ERCP-k számát [17]. Ennek a stratégiának az eredménye, hogy a diagnosztikus ERCP-k arányát egy prospektíven gyưjiött adatokat tartalmazó, több mint négyéves időszakban $3 \%$ alá tudtuk szorítani [18]. Mivel OD-ban igen magas a PEP aránya, kézenfekvő az OD diagnosztikájában és kezelésében az ERCP és a sphincterotomia előtt minden lehetőséget kihasználni, amint ezt egy 20 évvel ezelőtt e lap hasábjain megjelent tanulmányban olvashatjuk [19].

\section{Intravénás folyadékbevitel}

A heveny hasnyálmirigy-gyulladás kezelésében az első hat órában $250-500 \mathrm{~mL} / \mathrm{h}$, illetve az első 24 órában 2500-4000 mL mennyiségben adott (elsősorban Ringer-laktát) infúzióval szerzett kedvező tapasztalatok alapján kézenfekvő a PEP megelőzésére is az intenzív intravénás folyadékterápiát javasolni $[6,20]$. Az ajánlást retrospektív [21] elemzés és egy kis esetszámú prospektív tanulmány [22] erősítette meg.

\section{Kanülálási technika}

A korábban alkalmazott töltókatéter helyett a papillotommal végzett intubálás széles körben elfogadott [23]. Abban is egyetértés van, hogy a ductus choledochus vagy pancreaticus lumenébe mélyen bevezetett papillotommal végzett kontrasztanyagtöltés kisebb kockázattal jár, mint a szájadékra helyezett vagy a nem kellő mélységig bevezetett töltőkatéteren át történő kontrasztanyagadás. Ez ugyanis nemcsak submucosus depot képződése révén akár a vizsgálat folytatásának lehetőségét veszé- lyezteti, hanem súlyos PEP kialakulásának a kockázatával is jár. Amennyiben epeúti endoszkópos terápiát tervezünk, célszerű a hasnyálmirigy-vezeték kanülálását elkerülnünk, ha erre mégis sor kerül, a lehető legkevesebb kontrasztanyag adására kell törekednünk, ugyanis a ductus pancreaticus ismételt töltése, különösen az acinarisatio, emeli a PEP rizikóját [13, 24]. A kontrasztanyag ozmolalitása nem befolyásolja a PEP előfordulását [25].

\section{Vezetödróttal végzett intubálás}

Egy 2013-ban közzétett metaanalízis szerint a vezetődróttal végzett intubálás kevesebb PEP-hez vezet, mint a hagyományos technika [26]. Az e közleménnyel egy időben megjelent tanulmányok azonban kétségbe vonják ennek a technikának az előnyeit $[27,28]$. Saját gyakorlatunkban ötvöztük a két módszert, a betegek mintegy 70\%-át papillotommal sikeresen és alacsony PEP-aránynyal kanüláltuk, és öt sikertelen kísérlet után alkalmaztunk vezetődrótot $[8,18]$. A kettős vezetődróttal való kanülálás [29] helyett az előmetszés előnyösebbnek tünik $[6,30]$.

\section{A kanülálási kisérletek számának korlátozása és a korai elömetszés}

A kanülálási kísérletek számával együtt nő a PEP kockázata [1, 18, 31]. A korai előmetszés jobban növeli a sikeresség arányát, mint 10 sikertelen kanülálás után végzett további intubálási kísérletek [15]. Az előmetszést végezhetjük túkéssel a szájadékból kiindulva, az orifitum felett fistulaképzéssel vagy a ductus pancreaticusba helyezett stent felett. Papillotomot használhatunk a transpancreaticus sphincterotomiánál (septomia). Az előmetszés nagy gyakorlatot igényel, típusának kiválasztása a konkrét szituáció és vizsgáló tapasztalatainak függvénye, általános felfogás szerint a különböző módszerek egyenértékűek.

\section{Hasnyálmirigy-pezeték stentelése}

Magas PEP-kockázatú betegekben a hasnyálmirigy-vezetékbe történő rövid, $5 \mathrm{~F}$ átmérójü múanyag stent behelyezése csökkenti a PEP gyakoriságát [13], bár ennek sikertelensége növeli a PEP kockázatát [32], és minden betegben való alkalmazása nem költséghatékony [33]. Kialakult PEP esetén a ductus pancreaticus stentelése csökkenti a súlyos PEP kialakulásának a kockázatát [34].

\section{A PEP gyógyszeres megelözése}

A szomatosztatin analógjának, az octreotidnek az ERCP során a hasnyálmirigyre gyakorolt szerepét magyar szerzők is behatóan vizsgálták $[35,36,37,38]$. A szomatosztatinnak a PEP megelőzésében játszott szerepe máig tisztázatlan, a két legutóbb közzétett véletlen beválasztásos, ellenőrzött tanulmány ellentétes következte- 
tésre jutott $[39,40]$. A nitrát, különösen sublingualisan adva, a PEP megelözésében hatékonynak túnik [41], és egy tanulmányban bizonyították, hogy indometacinnal együtt alkalmazva a preventív hatás fokozódik [42].

Számos véletlen beválasztásos, ellenőrzött tanulmány és ezek nyomán született metaanalízis igazolta, hogy az ERCP előtt vagy után végbélkúpban alkalmazott 100 mg indometacin vagy diclofenac hatékony a PEP megelőzésében $[43,44]$. A saját vizsgálatunk szerint az indometacin végbélkúp elsősorban a magas kockázatú betegek és beavatkozások esetén effektív [18]. Betegeink 'post hoc' elemzése azt mutatta, hogy a 100 mg-os indometacin végbélkúp sem a szív- és keringési eredetû halálozást [45], sem a sphincterotomia utáni vérzés gyakoriságát nem növelte meg, még a napi $100 \mathrm{mg}$ szalicilátot szedőkben sem [46]. Úgy tünik, hogy az indometacin helyettesíti vagy akár fölülmúlja a PEP megelőzésében a hasnyálmirigy-vezetékbe profilaktikusan behelyezett múanyag stentet $[47,48]$, és effektív, ha a hasnyálmirigystent behelyezése sikertelen [49]. Az olcsó indometacin- vagy a diclofenackúp költséghatékonysága kiemelkedő [50].

\section{Következtetések}

A PEP megelőzésében olyan komplex stratégia a legeredményesebb, amely az ERCP-re kerülő beteg gondos kiválasztását, a kanülálási kísérletek számának korlátozását, a korai előmetszést, kellő mennyiségú infúzió adását, $100 \mathrm{mg}$ indometacin vagy diclofenac végbélkúp alkalmazását, valamint a magas kockázatú betegekben és/vagy a magas kockázatú beavatkozások során a ductus pancreaticusba stent behelyezését jelenti.

Anyagi támogatás: A közlemény megírása, illetve a kapcsolódó kutatómunka anyagi támogatásban nem részesült

Szerzői munkamegosztás: P. Á., P. Á. V.: Irodalomkutatás. P. Á., P. Á. V., S. N., T. Zs., H. L.: A kézirat megszövegezése. A cikk végleges változatát valamennyi szerző elolvasta és jóváhagyta.

Érdekeltségek: A szerzőknek nincsenek érdekeltségeik.

\section{Irodalom}

[1] Freeman, M. L., Nelson, D. B., Sherman, S., et al.: Complications of endoscopic biliary sphincterotomy. N. Engl. J. Med., 1996, 335(13), 909-918.

[2] Loperfido, S., Angelini, G., Benedetti, G., et al.: Major early complications from diagnostic and therapeutic ERCP: a prospective multicenter study. Gastrointest. Endosc., 1998, 48(1), 1-10.

[3] Nagy, G., Orosz, P.: Report of Hungarian gastrointestinal endoscopic activity in 2013. [Jelentés a 2013. évi magyarországi gasztroenterológiai endoszkópos tevékenységről.] Lege Artis Med., 2014, 24(8-9), 433-435. [Hungarian]
[4] Kochar, B., Akshintala, V. S., Afghani, E., et al.: Incidence, severity, and mortality of post-ERCP pancreatitis: a systematic review by using randomized, controlled trials. Gastrointest. Endosc., 2015, 81(1), 143-149.e9.

[5] ASGE Standards of Practice Committee, Anderson, M. A., Fisher, L., Jain, R., et al.: Complications of ERCP. Gastrointest. Endosc., 2012, 75(3), 467-473.

[6] Dumonceau, J. M., Andriulli, A., Elmunzer, B. J., et al.: Prophylaxis of post-ERCP pancreatitis: European Society of Gastrointestinal Endoscopy (ESGE) Guideline - Updated June 2014. Endoscopy, 2014, 46(9), 799-815.

[7] Hritz, I., Czakó, L., Dubravcsik, Z., et al.: Acute pancreatitis. Evidence based management guidelines of the Hungarian Pancreatic Study Group. [Acut pancreatitis. A Magyar Hasnyálmirigy Munkacsoport bizonyítékon alapuló kezelési irányelvei.] Orv. Hetil., 2015, 156(7), 244-261. [Hungarian]

[8] Patai, Á., Solymosi, N., Mobácsi, L., et al.: Prevention of postERCP pancreatitis: Review of current strategies in clinical practice. World J. Gastroenterol., 2015. [In press]

[9] Cotton, P. B., Lehman, G., Vennes, J., et al.: Endoscopic sphincterotomy complications and their management: an attempt at consensus. Gastrointest. Endosc., 1991, 37(3), 383-393.

[10] Banks, P. A., Bollen, T. L., Dervenis, C., et al.: Classification of acute pancreatitis - 2012: revision of the Atlanta classification and definitions by international consensus. Gut, 2013, 62(1), 102-111.

[11] Simon, L., Döbrönte, Z., Patai, Á.: Management of hypertensive dyskinesia of Oddi sphincter. Correlation between the frequency of complications from endoscopic sphincterotomy and the diameter of the common bile duct. [A hypertoniás Oddi-sphincter dyskinesis kezelése. Összefüggés az endoscopos sphincterotomia szövődményeinek gyakorisága és az epevezeték tágassága között.] Orv. Hetil., 1995, 136(31), 1659-1662. [Hungarian]

[12] Freeman, M. L., DiSario, J. A., Nelson, D. B., et al.: Risk factors for post-ERCP pancreatitis: a prospective, multicenter study. Gastrointest. Endosc., 2001, 54(4), 425-434.

[13] Freeman, M. L.: Post-ERCP pancreatitis: patient and techniquerelated risk factors. JOP, 2002, 3(6), 169-176.

[14] Masci, E., Mariani, A., Curioni, S., et al.: Risk factors for pancreatitis following endoscopic retrograde cholangiopancreatography: a meta-analysis. Endoscopy, 2003, 35(10), 830-834.

[15] Testoni, P. A., Mariani, A., Giussani, A., et al.: Risk factors for post-ERCP pancreatitis in high- and low-volume centers and among expert and non-expert operators: a prospective multicenter study. Am. J. Gastroenterol., 2010, 105(8), 1753-1761.

[16] Herszényi, L., Szmola, R., Tulassay, Z.: Clinical importance of pancreas divisum. [A pancreas divisum klinikai jelentősége.] Orv. Hetil., 2011, 152(44), 1764-1771. [Hungarian]

[17] Szalai, O., Hoffer, K., Ringelhan, B., et al.: The use of MRCP effectively decreases the complications of ERCP in patients with suspected pancreatobiliary tract diseases (Abstract). Z. Gastroenterol., 2010, 48, A80.

[18] Patai, Á., Solymosi, N., Patai, Á. V.: Effect of rectal indomethacin for preventing post-ERCP pancreatitis depends on difficulties of cannulation. Results from a randomized study with sequential biliary intubation. J. Clin. Gastroenterol., 2015, 49(5), 429437.

[19] Döbrönte, Z., Simon, L., Patai, Á.: Management of Oddi sphincter dyskinesis. Results of drug therapy and sphincterotomy. [Az Oddi-sphincter dyskinesis kezelése. A gyógyszeres terápia és a sphincterotomia eredményei.] Orv. Hetil., 1995, 136(40), 2165-2167. [Hungarian]

[20] Tenner, S., Baillie, J., DeWitt, J., et al.: American College of Gastroenterology guideline: Management of acute pancreatitis. Am. J. Gastroenterol., 2013, 108(9), 1400-1415.

[21] Sagi, S. V., Schmidt, S., Fogel, E., et al.: Association of greater intravenous volume infusion with shorter hospitalization for pa- 
tients with post-ERCP pancreatitis. J. Gastroenterol. Hepatol., 2014, 29(6), 1316-1320.

[22] Buxbaum, J., Yan, A., Yeh, K., et al.: Aggressive hydration with lactated Ringer's solution reduces pancreatitis after endoscopic retrograde cholangiopancreatography. Clin. Gastroenterol. Hepatol., 2014, 12(2), 303-307.el.

[23] Cortas, G. A., Mehta, S. N., Abraham, N. S., et al.: Selective cannulation of the common bile duct: a prospective randomized trial comparing standard catheters with sphincterotomes. Gastrointest. Endosc., 1999, 50(6), 775-779.

[24] Cheon, Y. K., Cho, K. B., Watkins, J. L., et al.: Frequency and severity of post-ERCP pancreatitis correlated with extent of pancreatic ductal opacification. Gastrointest. Endosc., 2007, 65(3), 385-393.

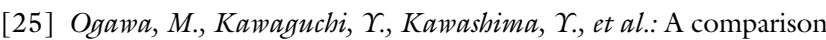
of ionic, monomer, high osmolar contrast media with non-ionic, dimer, iso-osmolar contrast media in ERCP. Tokai J. Exp. Clin. Med., 2013, 38(3), 109-113.

[26] Tse, F., Yuan, ., Moayyedi, P., et al.: Guide wire-assisted cannulation for the prevention of post-ERCP pancreatitis: a systematic review and meta-analysis. Endoscopy, 2013, 45(8), 605-618.

[27] Mariani, A., Giussani, A., Di Leo, M., et al.: Guidewire biliary cannulation does not reduce post-ERCP pancreatitis compared with the contrast injection technique in low-risk and high-risk patients. Gastrointest. Endosc., 2012, 75(2), 339-346.

[28] Kobayashi, G., Fujita, N., Imaizumi, K., et al.: Wire-guided biliary cannulation technique does not reduce the risk of postERCP pancreatitis: multicenter randomized controlled trial. Dig. Endosc., 2013, 25(3), 295-302.

[29] Gyökeres, T., Dubl, J., Varsányi, M., et al.: Double guide wire placement for endoscopic pancreaticobiliary procedures. Endoscopy, 2003, 35(1), 95-96.

[30] Yoo, Y.W., Cha, S. W., Lee, W. C., et al.: Double guidewire technique vs. transpancreatic precut sphincterotomy in difficult biliary cannulation. World J. Gastroenterol., 2013, 19(1), 108114 .

[31] Cennamo, V., Fuccio, L., Zagari, R. M., et al.: Can early precut implementation reduce endoscopic retrograde cholangiopancreatography-related complication risk? Meta-analysis of ran domized controlled trials. Endoscopy, 2010, 42(5), 381-388.

[32] Freeman, M. L., Overby, C., Qi, D.: Pancreatic stent insertion: consequences of failure and results of a modified technique to maximize success. Gastrointest. Endosc., 2004, 59(1), 8-14.

[33] Das, A., Singh, P., Sivak, M. V. Jr., et al.: Pancreatic-stent placement for prevention of post-ERCP pancreatitis: a cost-effectiveness analysis. Gastrointest. Endosc., 2007, 65(7), 960-968.

[34] Madácsy, L., Kurucsai, G., Joó, I., et al.: Rescue ERCP and insertion of a small-caliber pancreatic stent to prevent the evolution of severe post-ERCP pancreatitis: a case-controlled series. Surg. Endosc., 2009, 23(8), 1887-1893.

[35] Tulassay, Z., Papp, J.: The effect of long-acting somatostatin analogue on enzyme changes after endoscopic pancreatography. Gastrointest. Endosc., 1991, 37(1), 48-50.

[36] Tulassay, Z., Döbrönte, Z., Prónai, L., et al.: Octreotide in the prevention of pancreatic injury associated with endoscopic cholangiopancreatography. Aliment. Pharmacol. Ther., 1998 , 12(11), 1109-1112.

[37] Herszényi, L., Tulassay, Z.: Octreotide in the prevention of postERCP pancreatic injury. Am. J. Gastroenterol., 2007, 102(7), $1539-1540$
[38] Herszényi, L., Mibály, E., Tulassay, Z.: Somatostatin and gastrointestinal tract. Clinical experiences. [A szomatosztatin és az emésztő́rendszer. Klinikai tapasztalatok.] Orv. Hetil., 2013, 154(39), 1535-1540.

[39] Concepción-Martín, M., Gómez-Oliva, C., Juanes, A., et al.: Somatostatin for prevention of post-ERCP pancreatitis: a randomized, double-blind trial. Endoscopy, 2014, 46(10), 851856.

[40] Bai, Y., Ren, X., Zhang, X. F., et al.: Prophylactic somatostatin can reduce incidence of post-ERCP pancreatitis: multicenter randomized controlled trial. Endoscopy, 2015 Jan 15. [Epub ahead of print]

[41] Ding, J., Jin, X., Pan, Y., et al.: Glyceryl trinitrate for prevention of post-ERCP pancreatitis and improve the rate of cannulation: a meta-analysis of prospective, randomized, controlled trials. PLoS One, 2013, $8(10)$, e75645.

[42] Sotoudehmanesh, R., Eloubeidi, M. A., Asgari, A. A., et al.: A randomized trial of rectal indomethacin and sublingual nitrates to prevent post-ERCP pancreatitis. Am. J. Gastroenterol., 2014, 109(6), 903-909.

[43] Elmunzer, B. J., Waljee, A. K., Elta, G. H., et al.: A meta-analysis of rectal NSAIDs in the prevention of post-ERCP pancreatitis. Gut, 2008, 57(9), 1262-1267.

[44] Sun, H. L., Han, B., Zhai, H. P., et al.: Rectal NSAIDs for the prevention of post-ERCP pancreatitis: A meta-analysis of randomized controlled trials. Surgeon, 2014, 12(3), 141-147.

[45] McGettigan, P., Henry, D.: Cardiovascular risk and inhibition of cyclooxygenase: a systematic review of the observational studies of selective and nonselective inhibitors of cyclooxygenase 2 . JAMA, 2006, 296(13), 1633-1644.

[46] Patai, Á., Solymosi, N., Patai, Á. V.: Does rectal indomethacin given for prevention of post-ERCP pancreatitis increase bleeding after biliary endoscopic sphincterotomy or cardiovascular mortality? Post hoc analysis using prospective clinical trial data. Medicine (Baltimore), 2014, 93(26), el59.

[47] Elmunzer, B. J., Higgins, P. D., Saini, S. D., et al.: Does rectal indomethacin eliminate the need for prophylactic pancreatic stent placement in patients undergoing high-risk ERCP? Post hoc efficacy and cost-benefit analyses using prospective clinical trial data. Am. J. Gastroenterol., 2013, 108(3), 410-415.

[48] Akbar, A. A., Abu Dayyeh, B. K., Baron, T. H., et al.: Rectal nonsteroidal anti-inflammatory drugs are superior to pancreatic duct stents in preventing pancreatitis after endoscopic retrograde cholangiopancreatography: a network meta-analysis. Clin. Gastroenterol. Hepatol., 2013, 11(7), 778-783.

[49] Choksi, N. S., Fogel, E. L., Cote, G. A., et al.: The risk of postERCP pancreatitis and the protective effect of rectal indomethacin in cases of attempted but unsuccessful prophylactic pancreatic stent placement. Gastrointest. Endosc., 2015, 81(1), $150-155$

[50] Nicolás-Pérez, D., Castilla-Rodríguez, I., Gimeno-García, A. $Z$., et al.: Prevention of post-endoscopic retrograde cholangiopancreatography pancreatitis: A cost-effectiveness analysis. Pancreas, $2015,44(2), 204-210$.

(Patai Árpád dr., Szombathely, Markusovszky L. u. 5., 9700 e-mail: pataiarpaddr@gmail.com) 